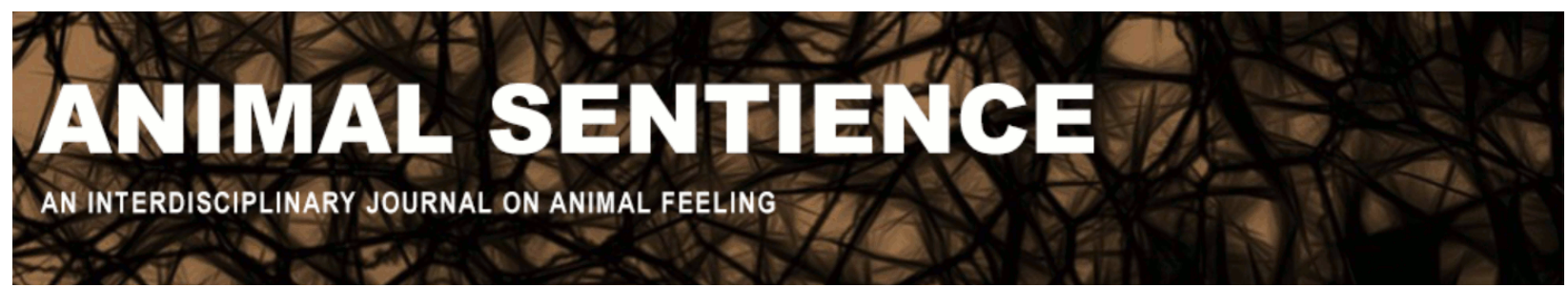

Li, Peter J. (2016) Animal suffering in China. Animal Sentience 7(8)

DOI: $10.51291 / 2377-7478.1093$

Date of submission: 2016-02-21

Date of acceptance: 2016-02-24

(c) (i)

This article has appeared in the journal Animal

Sentience, a peer-reviewed journal on animal

cognition and feeling. It has been made open access,

free for all, by WellBeing International and deposited

in the WBI Studies Repository. For more information,

please contact

wbisr-info@wellbeingintl.org.

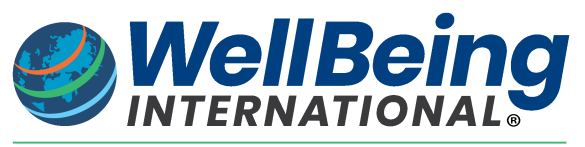

SOLUTIONS FOR PEOPLE, ANIMALS AND ENVIRONMENT 


\title{
Animal suffering in China
}

Commentary on $\mathrm{Ng}$ on Animal Suffering

Peter J. Li

Department of Political Science

University of Houston-Downtown

\begin{abstract}
Chinese policy has been aimed at maximizing GDP; it is time to focus also on minimizing animal suffering.
\end{abstract}

Peter J. Li lip@uhd.edu specializes in China's domestic and foreign policies, environmental and wildlife policy, and political and social transformation under conditions of economic modernization. He consults for

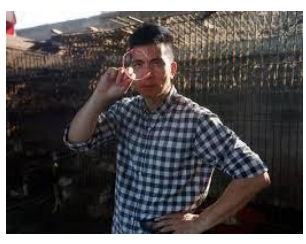
Humane Society International on animal welfare policy issues in China and other East Asian nations.

https://www.uhd.edu/academics/humanities/undergraduateprograms/political-science/Pages/political-science-lip.aspx

As a political scientist, I have been asked why my work does not seem to have much to do with "high political" issues of foreign policy, nuclear security or geopolitics. It was the politics of animal treatment that drew me into this developing field. The work of $\mathrm{Ng}$ (2016), an economist by training, is another example of the importance of animal welfare problems to scholars of diverse academic backgrounds.

Ng's three "simple ways" to reduce animal suffering - regulation, prohibition of cruelty, and less emphasis on GDP - seem to be addressed to China specifically, the country of my expertise. The first two ways are urgently needed there while the third constitutes a direct challenge to the dominant thinking of the Chinese government about modernization. Regulation of the animal industry is a daunting task throughout the world, but especially in mainland China where livestock production, wildlife farming, captive wildlife used for display and research, and fur farming have become a gigantic enterprise. During the Mao era not too long ago, China underwent devastating hunger. Those over the age of 55 are still haunted by memories of the Maoist "tyranny of scarcity." Animal industries have exploited this fear to sabotage attempts at animal welfare regulation. Politically, food security and its implications for regime stability remain a top priority for the Chinese leadership. This explains why China has the world's unique "strategic pork reserve" system to ensure pork supply and preempt public discontent. In the foreseeable future, regulations for improving the welfare of farm animals in the country are unlikely to be among the government's policy-making priorities. On the contrary, the authorities have been pushing for accelerating livestock production (State Council 2001). Animal welfare 
regulations are a simple approach that could cause a sweeping change if adopted, but there is a lot of resistance to overcome before the government can sit down to draft the regulations.

Any call to prohibit gratuitous cruelty is welcome. However, most cruelty is a feature of abusive practices that should not have been implemented in the first place. Whipping racehorses might be unnecessary, but racing itself is forced upon the horses for human entertainment or gambling. The cutting of eels while they are still alive is cruel, but the consumption of eels, caught from the wild is already a big environmental issue, with many adverse effects on the ecosystem. The bear farming in East and South East Asia is intrinsically cruel because bile extraction entails great pain (Loeffler et al., 2007). "We also have to deny them food they like," a bear farm owner told me in 2004 in Chengdu. "If they eat too well, their bile will be used for processing and digesting the food and the amount we can extract will be reduced." Similarly, foie gras production, zoo animal performance, killer whale shows, and the dog meat trade are intrinsically cruel. These industries are modern slavery systems. What need to be prohibited are the products and industries that give rise to such suffering.

The obsession with GDP and its growth was Western in origin. W.W. Rostow's The Stages of Economic Growth: A Non-Communist Manifesto (1960) helped increase the popularity of the Western modernization model across the non-Communist developing world. Expansion of GDP was the way out of poverty and a bridge from the "takeoff" stage to the end stage of "mass consumption." The spectacular post-War economic recovery of West Germany and Japan, as indicated by their breathtaking GDP growth rates, encouraged the Asian "four dragons" (Hong Kong, Singapore, South Korea, and Taiwan) to pursue GDP expansion. Despite its Leninist Partystate political system, mainland China has pursued a modernization strategy dubbed "GDP worship" by the media (Brown 2014). Productivity, efficiency, new technologies, new production models such as the Western factory farming system, and the building of a technocratic bureaucracy are all aimed at GDP expansion. This Chinese modernization strategy is a replica of the experience of Western Europe, North America, Japan and the "four Asian dragons." In the words of a renowned scholar (Cummings 1999), this strategy does promote industrialization, but not enlightenment. Political liberalization and environmental movements are suppressed, not encouraged. The Chinese GDP worship does have a uniquely Chinese rationale too, namely, its importance for regime stability. To the Chinese authorities, GDP growth is crucial for the food supply, employment, poverty reduction and the reconstruction of the legitimacy of the Communist Party (Central Document Research Institute 2004).

"Further increases in an individual's consumption do not really increase happiness significantly," observes $\mathrm{Ng}$, and "economic growth may be (human) welfare-decreasing." China is a case in point. Developmental efforts in China have indeed succeeded in enlarging the GDP and lifting hundreds of millions of Chinese out of abject poverty, an accomplishment acknowledged by the UN (2010). Today, China is reportedly the world's biggest consumer of luxury products (China Daily 2014). China's meat output (not including sea fish and fish farming output) has reached 83 million metric tons, more than double the output of the U.S., the distant second biggest producer (FAOSTAT, 2013). Whereas Chinese consumers have no idea of the welfarecompromised conditions on the industrialized animal farms, meat and dairy abundance has not 
been translated into human welfare. According to Chinese official statistics, the country has about 230 million people with cardiovascular disease: this means one out of five adults (WHO 2015). In 2013, one in four people with diabetes in the world was Chinese. Among adults in China, $12 \%$ were diabetic and $50 \%$ were pre-diabetic. Many more were among the undiagnosed, untreated, or uncontrolled (Chan et al. 2014). A World Health Organization (WHO) report that reads "China: Cancer Rates Growing 'Ferociously'" highlights the disconnect between increased personal consumption and human welfare. According to the WHO (2015), China had 2.2 million cancer-related deaths in 2014.

China is at a historical juncture. It is time to stop the focus on GDP and begin policy-making in favor of environmental justice and animal welfare. Animal suffering is real. The natural human reaction to animals in distress is strong enough to awaken skeptics. Making science and industry humane will take time, but $\mathrm{Ng}$ 's welfare biology is a step in the right direction.

\section{References}

Bermond, B. (2003). The Myth of Animal Suffering. In S. J. Armstrong and R. G. Botzler (Eds.), The Animal Ethics Reader. Routledge, New York.

Browne, A. (2014) Beijing Should Scrap the GDP Target. Wall Street Journal.

Chan, J. C. N., Zhang, Y., \& Ning, G. (2014). Diabetes in China: A societal solution for a personal challenge. The Lancet.

Chang, L. (2014). China: World's biggest luxury consumer. China Daily. February 21.

Chinese Communist Party Central Document Research Institute. (2004). Chronicle of Deng Xiaoping's Life: 1975-1997 (deng Xiaoping nianpu), Vol. 2. CCP Central Archive Press, Beijing: 380-381, 450-451.

Cruelty Free International. (2015). Facts and Figures on Animal Testing.

Cumings, B. (1996). Chapter 3, Webs with No Spiders, Spiders with No Webs: The Genealogy of the Developmental State. In M. Woo-Cumings (Ed.), The Developmental State. The Cornell University Press, Ithaca, N.Y.: 70.

Easton, D. (1996). The Idea of a Political System and the Orientation of Political Research. In J. Farr and Raymond Seidelman (Eds.), Discipline and History: Political Science in the United States. The University of Michigan Press, Ann Arbor: 229.

FAOSTAT. (2016). China Meat Output in 2013. Food and Agriculture Organization of the United Nations database. 
Loeffler, K., Robinson, J., \& Cochrane, G. (2007). Compromised Health and Welfare of Bears in China's Bear Bile Farming Industry with Special Reference to the Free-dripping Bile Extraction Technique. Animals Asia Foundation report.

$\mathrm{Ng}$, Y-K. (2016) How welfare biology and commonsense may help to reduce animal suffering. Animal Sentience 2016.007.

Rolin, B. E. (2003). Scientific Ideology, Anthropomorphism, Anecdote, and Ethics. In S. J. Armstrong and R. G. Botzler (Eds.), The Animal Ethics Reader: 67-74.

State Council. (2001). Recommendations on Accelerating Livestock Production. Issued by the Agriculture Ministry.

United Nations. (2010). Rethinking Poverty: Report on the World Social Situation 2010.

World Health Organization Representative Office in China. (2015). Cardiovascular Diseases: The Situation in China.

World Health Organization Representative Office in China. (2015). China: Cancer Rates Growing 'Ferociously'. 